\title{
Recent advances in managing triple-negative breast cancers
}

\section{Carmelo Bengala}

\author{
Address: Division of Medical Oncology, Department of Oncology, Hematology and Respiratory Diseases, University Hospital, University of \\ Modena and Reggio Emilia, Via del Pozzo, 71 - 41100, Modena, Italy \\ Email: bengala.carmelo@unimore.it
}

FI000 Medicine Reports 2009, I:75 (doi:10.3410/MI-75)

The electronic version of this article is the complete one and can be found at: http://FI000.com/Reports/Medicine/content/I/75

\begin{abstract}
Triple-negative breast cancer (TNBC) has been recently recognized as an important subgroup of breast cancer with a distinct outcome and therapeutic approach compared with other breast cancer subgroups. Because TNBC is defined by the absence of a target (either hormone receptors or HER-2), conventional cytotoxic therapy is still the mainstay of treatment. This report focuses on the current state and recent advances in managing TNBC.
\end{abstract}

\section{Introduction and context}

Triple-negative breast cancer (TNBC) is defined by a lack of expression of estrogen and progesterone receptors and HER-2 as evaluated by immunohistochemistry methods. This subgroup accounts for about $15 \%$ of all types of breast cancers. Histologically, these tumors are poorly differentiated and express cytokeratins 5/6 and 17 . Additional biological characteristics of this subtype are epidermal growth factor receptor (EGFR) and c-KIT overexpression in $57 \%$ and $31 \%$ of cases, respectively [1]. Genomic expression profiling of this disease subtype has associated it with basal cells of the mammary epithelium (basal-like subtype) [2]. The basal-like breast cancer subtype expresses a highly angiogenic phenotype, includes many BRCA1-mutated tumors and has a poor prognosis $[2,3]$. Furthermore, an earlier age of onset, a high rate of local relapse, a higher incidence of visceral metastases, and a high rate of cerebral metastases have been reported in patients with basal-like breast cancer $[4,5]$. The basal-like subtype is assigned by gene expression profiling whereas the definition of TNBC is based on immunohistochemical characteristics. Moreover, it is crucial to note that although most basal-like cancers are triple negative, there is a moderate discordance between TNBC and basal-like breast cancer. Although most basal-like cancers do not express estrogen and progesterone receptors and HER-2, a small number do and, therefore, the overlap between basal-like breast cancer and TNBC is not complete and the terms are not completely synonymous. Because of this discordance and potential misclassification, in this review we refer to basal-like breast cancer when a gene expression array was used for characterization and to the TNBC subtype when the analysis was limited to immunohistochemistry.

Preclinical studies on BRCA1-related breast cancers have shown high sensitivity to alkylating agents, mitomycin$\mathrm{C}$, and platinum compounds as well as sensitivity to agents inducing DNA double-strand breaks such as etoposide and bleomycin, but resistance to mitoticspindle poisons such as taxanes and vinca alkaloids has been recorded [6]. Multiple data have consistently identified a poorer clinical outcome for women with basal-like breast cancer, although modern regimens of chemotherapy can alter the history of the disease [7]. The risk of recurrence is higher in the first 3-5 years, suggesting that a substantial number of women are cured if they remain disease-free for several years after diagnosis $[8,9]$. A retrospective analysis of the Cancer and Leukemia Group B (CALGB) 9344 trial found that patients with either TNBC or HER-2-positive breast cancer achieved the greatest benefit from the addition of paclitaxel to doxorubicin and cyclophosphamide [10]. Similarly, dose-dense therapy seems to have the greatest incremental benefit in women with estrogen receptorpositive tumors [11]. Pathological and molecular determinants of the chemosensitivity of breast cancers have been extensively explored through neoadjuvant trials. 
Estrogen receptor negativity and high expression of Ki67, features inherent to basal-like cancers, have been consistently shown to be associated with clinical and pathological responsiveness to neoadjuvant chemotherapy $[12,13]$. In the neoadjuvant setting, basal-like breast cancer has been associated with a significantly higher rate of pathological complete response; however, relapse-free and overall survival were very short [14-16]. On the basis of limited clinical data, the TNBC subtype is probably the most chemosensitive subtype of breast cancer, although it is unclear which agents induce the best response rate. From a biological stand point, DNAdamaging agents, such as platinating agents, are very high priority candidate agents based on the BRCA1 and DNA repair dysfunction described in TNBC. Two studies of neoadjuvant single agent cisplatin in women with TNBC and women with both BRCA1 mutations and TNBC have reported pathological complete response in $23 \%$ and $72 \%$ of cases, respectively $[17,18]$. These results further support research into the utility of platinum compounds in TNBC.

\section{Recent advances}

Several new drugs, including anti-angiogenic agents, EGFR inhibitors, poly(ADP-ribose) polymerase (PARP) inhibitors and Src kinase inhibitors, are currently under investigation for use in metastatic TNBC.

Based on EGFR expression in gene profiling studies and the dependence of basal-like breast cancer cell lines on EGFR for growth and proliferation, several groups have examined EGFR-targeting agents in TNBC. The TBCRC (Translational Breast Cancer Research Consortium) 001 trial was a randomized trial of carboplatin in combination with cetuximab versus cetuximab alone in patients with metastatic TNBC. A crossover to carboplatin at progression was planned. The response rate to the combination was $17 \%$, with a clinical benefit seen in $29 \%$ of patients [19]. A similar study of irinotecan plus carboplatin with or without cetuximab in metastatic breast cancer suggested, on subset analysis, a modest higher response rate $30 \%$ versus $40 \%$ ) for the patients with TNBC receiving cetuximab [20]. The role of anti-angiogenic therapy in TNBC has been evaluated retrospectively on a subset analysis in the ECOG (Eastern Cooperative Oncology Group) 2100 trial. The trial randomized patients with metastatic disease to receive palitaxel plus bevacizumab or paclitaxel alone as the first line of treatment. There was a significant improvement of progression-free survival with the addition of bevacizumab, including in the subgroup of patients with largely TNBC [21]. A prospective trial of neoajuvant cisplatin plus bevacizumab in TNBC showed a pathological response (Miller-Payne grade 4-5) of 36\%. [22]. Additional benefits from combining carboplatin and paclitaxel and the addition of bevacizumab to paclitaxel in TNBC will be directly studied in the neoadjuvant trial CALGB 40603, which has a $2 \times 2$ randomized bi-factorial design.

Other novel agents of interest include the multitarget Src kinase inhibitor dasatinib. A preclinical in vitro model of sensitivity of dasatinib applied to expression profiles from human tumors overlapped significantly with TNBC tumors, suggesting promising activity [23]. However, data from a phase II trial showed it had modest activity as a single agent [24]. PARPs are molecules integrally involved in nonhomologous DNA repair that become the primary means of double-strand DNA repair when the preferred homologous recombinant mechanism is lost, as occurs when the BRCA1 pathway is defective. BRCA1 loss or inactivation thus sensitizes cells to PARP inhibitors [25]. Dysfunction of BRCA1 pathways is present in hereditary breast cancer and in some TNBC cases. Recently, data from two phase II clinical trials of PARP inhibitors have been presented. Olaparib is an oral PARP inhibitor and, as a single agent, showed substantial activity in heavily pretreated BRCA1/BRCA2 carriers with advanced breast cancer: the overall response rate was $41 \%$ and the median progression-free survival was 5.7 months [26]. O'Shaughnessy et al. [27] presented data from a phase II randomized trial of carboplatin plus gemcitabine with or without BSI-201, a small-molecule PARP inhibitor, in patients with metastatic TNBC. The experimental regimen including BSI-201 showed a significantly improved response rate $(48 \%$ versus $16 \%)$, clinical benefit rate (62\% versus $21 \%)$, median progression-free survival (6.9 versus 3.3 months) and median overall survival (9.2 versus 5.7 months) [27].

\section{Implications for clinical practice}

In the adjuvant and curative setting, TNBC should be treated with conventional therapies at this time. Despite promising data from preclinical models and early phase clinical trials, incorporation of platinum compounds or other novel therapies should await further confirmation from phase III clinical trials. Retrospective correlative strategies focusing on the TNBC subgroup may help to identify which patients will benefit most from standard drugs. The recent advances should not change clinical practice at this time. However, patients with TNBC should be offered clinical trials looking at the efficacy and safety of new drugs. Results from ongoing clinical trials will soon provide information to enable us to change therapeutic approaches to TNBC.

\section{Abbreviations}

ECOG, Eastern Cooperative Oncology Group; EGFR, epidermal growth factor receptor; CALGB, Cancer and 
Leukemia Group B; PARP, poly(ADP-ribose) polymerase; TBCRC, Translational Breast Cancer Research Consortium; TNBC, triple-negative breast cancer.

\section{Competing interests}

The author declares that he has no competing interests.

\section{References}

I. Nielsen TO, Hsu FD, Jensen K, Cheang M, Karaca G, Hu Z, Hernandez-Boussard T, Livasy C, Cowan D, Dressler L, Akslen LA, Ragaz J, Gown AM, Gilks CB, van de Rijn M, Perou CM: Immunohistochemical and clinical characterization of the basal-like subtype of invasive breast carcinoma. Clin Cancer Res 2004, 10:5367-74.

2. Sørlie T, Tibshirani R, Parker J, Hastie T, Marron JS, Nobel A, Deng S, Johnsen H, Pesich R, Geisler S, Demeter J, Perou CM, Lønning PE, Brown PO, Børresen-Dale AL, Botstein D: Repeated observation of breast tumor subtypes in independent gene expression data sets. Proc Natl Acad Sci U S A 2003, 100:8418-23.

3. Sørlie T, Perou CM, Tibshirani R, Aas T, Geisler S, Johnsen H, Hastie T, Eisen MB, van de Rijn M, Jeffrey SS, Thorsen T, Quist H, Matese JC, Brown PO, Botstein D, Eystein Lønning P, BørresenDale AL: Gene expression patterns of breast carcinomas distinguish tumor subclasses with clinical implications. Proc Natl Acad Sci U S A 200 I, 98: 10869-74.

4. Perou CM, Sørlie T, Eisen MB, van de Rijn M, Jeffrey SS, Rees CA, Pollack JR, Ross DT, Johnsen $H$, Akslen LA, Fluge $O$, Pergamenschikov A, Williams C, Zhu SX, Lønning PE, BørresenDale AL, Brown PO, Botstein D: Molecular portraits of human breast tumors. Nature 2000, 406:747-52.

5. Osborne CR, Kannan L, Ashfaq R, Ariyibi J, Frawley WH, Tripathy D: Clinical and pathological characterization of basal-like breast cancer. Breast Cancer Res Treat 2005, 94(Suppl I):SI I8, Abstract 2098.

6. Rodríguez-Pinilla SM, Sarrió D, Honrado E, Hardisson D, Calero F, Benitez J, Palacios J: Prognostic significance of basal-like phenotype and fascin expression in node-negative invasive breast carcinomas. Clin Cancer Res 2006, I2:1533-9.

7. Rakha EA, Reis-Filho JS, Ellis IO: Basal-like breast cancer: a critical review. J Clin Oncol 2008, 26:2568-8I.

8. Dent R, Trudeau M, Pritchard KI, Hanna WM, Kahn HK, Sawka CA, Lickley LA, Rawlinson E, Sun P, Narod SA: Triple negative breast cancer: clinical features and patterns of recurrence. Clin Cancer Res 2007, 13:4429-34.

9. Liedtke C, Mazouni C, Hess KR, André F, Tordai A, Mejia JA, Symmans WF, Gonzalez-Angulo AM, Hennessy B, Green M, Cristofanilli M, Hortobagyi GN, Pusztai L: Response to neoadjuvant therapy and long-term survival in patients with triplenegative breast cancer. J Clin Oncol 2008, 26:1275-8I.

10. Hayes DF, Thor AD, Dressler LG, Weaver D, Edgerton S, Cowan D, Broadwater G, Goldstein LI, Martino S, Ingle JN, Henderson IC, Norton L, Winer EP, Hudis CA, Ellis MJ, Berry DA; Cancer and Leukemia Group B (CALGB) Investigators: HER2 and response to paclitaxel in node-positive breast cancer. N Engl J Med 2007, 357:1496-506.

FI000 Factor 3.0 Recommended Evaluated by Debu Tripathy 7 Nov 2007

II. Citron ML, Berry DA, Cirrincione C, Hudis C, Winer EP, Gradishar WJ, Davidson NE, Martino S, Livingston R, Ingle JN, Perez EA, Carpenter J, Hurd D, Holland JF, Smith BL, Sartor Cl, Leung EH, Abrams J, Schilsky RL, Muss HB, Norton L: Randomized trial of dose-dense versus conventionally scheduled and sequential versus concurrent combination chemotherapy as postoperative adjuvant treatment of node-positive primary breast cancer: first report of Intergroup Trial C974I/Cancer and Leukemia Group B Trial 974I. J Clin Oncol 2003, 2 I: |43I-9.

12. Guarneri V, Broglio K, Kau SW, Cristofanilli M, Buzdar AU, Valero V, Buchholz T, Meric F, Middleton L, Hortobagyi GN, GonzalezAngulo AM: Prognostic value of pathologic complete response after primary chemotherapy in relation to hormone receptor status and other factors. J Clin Oncol 2006, 24:1037-44.

13. Urruticoechera A, Smith IE, Dowsett M: Proliferation marker Ki67 in early breast cancer. J Clin Oncol 2005, 23:72 I2-20.

14. Foulkes WD: BRCAI and BRCA2: chemosensitivity, treatment outcomes and prognosis. Fam Cancer 2006, 5:135-42.

15. Rouzier R, Perou CM, Symmans WF, Ibrahim N, Cristofanilli M, Anderson K, Hess KR, Stec J, Ayers M, Wagner P, Morandi P, Fan C, Rabiul I, Ross JS, Hortobagyi GN, Pusztai L: Breast cancer molecular subtypes respond differently to preoperative chemotherapy. Clin Cancer Res 2005, I I:5678-85.

16. Carey LA, Dees EC, Sawyer L, Gatti L, Moore DT, Collichio F, Ollila DW, Sartor Cl, Graham ML, Perou CM: The triple negative paradox: primary tumor chemosensitivity of breast cancer subtypes. Clin Cancer Res 2007, 13:2329-34.

17. Garber JE, Richardson A, Harris LN, Miron A, Silver D, Golshan M, Ryan PD, Ganesan S, Li X, Wang ZC, Clarke K, Tung NM, Iglehart JD, Winer EP: Neo-adjuvant cisplatin (CDDP) in "triple negative" breast cancer (BC). Breast Cancer Res Treat 2006, 100 (SupplI) SI 49, Abstract 3074.

18. Gronwald J, Byrski T, Huzarski T, Dent R, Bielicka V, Zuziak D, Wisniowski R, Lubinski J, Narod S: Neoadjuvant therapy with cisplatin in BRCAI-positive breast cancer patients. J Clin Oncol 2009, 27 (Suppl I5s):502.

19. Carey LA, Rugo HS, Marcom PK, Irvin W Jr, Ferraro M, Burrows E, $\mathrm{He}$ X, Perou CM, Winer EP; on behalf of the Translational Breast Cancer Research Consortium: TBCRC 00 I: EGFR inhibition with cetuximab added to carboplatin in metastatic triple negative (basal-like) breast cancer. J Clin Oncol 2008, 26 (Suppl I5s): 1009.

20. O'Shaughnessy J, Weckstein DJ, Vukelja SJ, Mclntyre K, Krekow L, Holmes FA, Asmar L, Blum JL: Preliminary results of a randomized phase II study of weekly irinotecan/carboplatin with or without cetuximab in patients with metastatic breast cancer. Breast Cancer Res Treat 2007, 106 (Suppl I):S32, Abstract 308.

21. Miller K, Wang M, Gralow J, Dickler M, Cobleigh M, Perez EA, Shenkier T, Cella D, Davidson NE: Paclitaxel plus bevacizumab versus paclitaxel alone for metastatic breast cancer. $N$ Engl J Med 2007, 357:2666-76.

Changes Clinical Practice

FI000 Factor 6.0 Must Read

Evaluated by Debu Tripathy 28 Jan 2008

22. Ryan PD, Tung NM, Isakoff SJ, Golshan M, Richardson A, Corben AD, Smith BL, Gelman R, Winer EP, Garber JE: Neoadjuvant cisplatin and bevacizumab in triple negative breast cancer (TNBC): safety and efficacy. J Clin Oncol 2009, 27(Suppl I5s):55I.

23. Huang F, Reeves K, Han X, Fairchild C, Platero S, Wong TW, Lee F, Shaw P, Clark E: Identification of candidate molecular markers predicting sensitivity in solid tumors to dasatinib: rationale for patients selection. Cancer Res 2007, 67:2226-38.

24. Finn RS, Bengala C, Ibrahim N, Strauss LC, Fairchild J, Sy O, Roche H, Sparano J, Goldstein LJ: Phase II trial of dasatinib in triplenegative breast cancer: results of study CAI80059. Cancer Res 2009, 69 (Suppl 2):3118.

25. McCabe N, Turner NC, Lord CJ, Kluzek K, Bialkowska A, Swift S, Giavara S, O'Connor MJ, Tutt AN, Zdzienicka MZ, Smith GC, Ashworth A: Deficiency in the repair of DNA damage by homologous recombination and sensitivity to poly(ADPribose) polymerase inhibition. Cancer Res 2006, 66:8109-15.

26. Tutt A, Robson M, Garber JE, Domchek S, Audeh MW, Weitzel JN, Friedlander M, Carmichael J: Phase II trial of the oral PARP inhibitor olaparib in BRCA-deficient advanced breast cancer. J Clin Oncol 2009, 27 (Suppl I8s):CRA50I.

27. O'Shaughnessy J, Osborne C, Pippen J, Yoffe M, Patt D, Monaghan G, Rocha C, Ossovskaya V, Sherman B, Bradley C: Efficacy of BSI-20I, a poly (ADP-ribose) polymerase-I (PARPI) inhibitor, in combination with gemcitabine/carboplatin $(G / C)$ in patients with metastatic triple-negative breast cancer (TNBC): Results of a randomized phase II trial. J Clin Oncol 2009, 27(Suppl I8s):3. 